\title{
QUALITY AND SAFETY ASSESSMENT OF EGYPTIAN MARKETED FLAVOURED UHT MILK: A SURVEY STUDY FOR SANITARY MONITORING
}

\author{
Eslam A. Abdel Ghaffar*, A.A. El-Neshawy, H.M. Siliha and Gehan A. El-Shorbagy \\ Food Sci. Dept., Fac. Agric., Zagazig Univ., Egypt
}

Received: 26/02/2019 ; Accepted: 31/03/2019

\begin{abstract}
A total of 120 flavoured UHT milk samples $(200 \mathrm{ml})$ of two flavours (strawberry and mango) from three commercial plants (Brand A, brand B and non-branded plants) 20 samples of each flavoured UHT milk carton packaged were purchased from different markets, 6 October city, Egypt in 2017 and 2018. Results showed that, the pH and acidity recorded were consistent with the Egyptian Organization for Standardization and Quality (Ecorys) Specification, 2005. Antibiotics were present in 5\% of brand A mango samples and was clear in the non-branded milk being $10 \%$ and $15 \%$ in strawberry and mango milks, respectively. Formaldehyde was completely absent from all samples investigated, but hydrogen peroxide was detected in the non-branded mango and strawberry milk and valued as $20 \%$ and $5 \%$, respectively. Microbiological results revealed that total bacterial count (TBC) was not detected from any of the branded mango and strawberry UHT milk but a ratio of $15 \%$ of the non-branded strawberry milk samples was detected. Salmonella was completely absent in branded UHT milk samples. Coliforms not detected in brand A and B samples but $5 \%$ of mango and $10 \%$ of strawberry of non-brand milk samples were contaminated with coliforms. Yeasts and moulds were only detected in the non-branded UHT flavoured milk (5\% of mango and $15 \%$ of strawberry). Fat content recorded range among all samples (1.6\%-1.81\%) were not consistent with the Ecorys Specification, 2005 (3\%). TS and SNF values were consistent with the Egyptian UHT milk Specification $(\geq 15 \%)$ and protein values were within the accepted range.
\end{abstract}

Key words: Monitoring program, processed milk, flavoured UHT milk, brand, non-brand.

\section{INTRODUCTION}

As the society has developed over time, the feeding system has transformed into a widespread and complex global system throughout centuries. The commitment of food science and technology professionals to improve food science, supply safe and abundant food, and contribute people to be healthier is an inseparable part of this evolution (Floros et al., 2010). Food processing can be described as the transformation of raw ingredients and intermediate products into products, designed for human consumption, in order to improve the bioavailability, flavour, appearance, safety, storability and distribution of foodstuff and energy (Langelaan et al., 2013). The rules of food production and processing are changing in parallel with consumer expectations. The designs; more hygienic, reducing yield loss, prolonging shelf life, each stage of which can be monitored and controlled are included in product processing operations (Anonymos, 2005).

Many efforts have been made in the processed food sector that covers thousands of industrial food products from simple bread to vegetables, fruits and ready-made meals. Last few decades many efforts have been made to grow and improve this sector. The demand for variety of processed food by the growing numbers of consumers resulted in the constant expansion of this industry (Ahmedsham et al., 2018).

\footnotetext{
* Corresponding author: Tel. : +201000614051

E-mail address: eslamatifsaeed@yahoo.com
} 
Food processing recently plays a major role in Egypt where it is considered the supply of the food needs of the Egyptian population and there are over 7,000 food processing and manufacturing plants in Egypt including milk, savory snacks, and yoghurt and sour milk, processed fruits and vegetables, meats, seafood, rice, and pasta.

Consumers worldwide always demand food safety to have their foods of high standards and better quality. The term quality is defined as an important character, a degree of excellence or a necessary attribute. A group of activities designed to assure a standard of excellence are called Quality Control (QC), which is an essential component of any food business and not an option in the food processing sector; there are a strategies are needed to ensure that every ingredient maintains its quality and safety through all processing stages. The purposes of quality control are to protect the beneficiaries from dangers (e.g. contaminated foods) and ensure that they get the quality of product that they need (FDA, 2001). The growing demand for high-quality food products has disseminated the use of quality management tools to meet expectations of consumers and market throughout the world and reducing costs and production losses (Dias et al., 2010).

To apply a quality control program, you must define expected food quality to provide a system of quality measurement, allow a means for action not reaction by working with preventing action not correction action. The implementation of Good Manufacturing Practices (GMP) is one way to achieve a high standard of food quality. These practices consist of a set of principles and rules for the proper handling of food, ranging from the receipt of raw materials to the final product, with the main objective of ensuring the integrity of food and consumer health (Dias et al., 2010). Hazard Analysis and Critical Control Point System (HACCP) has been recognized as an effective and rational means of assuring food safety. The application of this preventive oriented approach through applying of multiple analytical methods would give the food producer better control over operation, better manufacturing practices and greater efficiencies, including reduced wastes (El-Hofi et al., 2010).
Although total quality management (TQM) and also its prerequisite programs have been discussed; Little work has been done on how this concept could be formally introduced to the area of food processing.

All over the world, milk is one of the most important human food and a biological fluid which contains a wide variety of different constituents and possesses unique physical and chemical characteristics. Milk quality is determined by aspects of composition and hygiene. The hygienic parameters are decisive for food safety and might also influence the composition of milk. A test for assessing compositional quality has to be judged on three bases: it must show physical, chemical and nutritional value, be equitable and practical. Protein, fat, vitamins and minerals are the constituents of milk which provide human nutritional needs, and the most valuable constituent is protein. Therefore the present study was carried out to assess quality and safety of marketed strawberry and mango flavoured UHT milk as survey study for sanitary monitoring of these products either brand or non- brand distributed at the Egyptian market.

\section{MATERIALS AND METHODS}

\section{Sample Collection}

A total of 120 flavoured UHT milk samples (each $200 \mathrm{ml}$ ) of two flavours (strawberry and mango) from three commercial plants (Brand A, brand $\mathrm{B}$ and non-branded plant). 20 samples of each flavour, carton packaged were purchased from different markets, 6 October city, Egypt in 2017 and 2018.

\section{Physcio-Chemical Analysis of Flavoured Milk}

\section{Determination of $\mathrm{pH}$ and titratable acidity}

$\mathrm{pH}$ was determined using the METTLER TOLEDO FE20-Basic Five Easy Bench Top Ph Meter, Switzerland. Acidity was determined according to AOAC (1990).

\section{Detection of formaldehyde}

This test was carried out using Quantofix formaldehyde kit (Sigma-Aldrich, Germany). 
With measuring colour range and number of determinations (0-10-20-40-60-100mg/HCHO).

\section{Hydrogen peroxide test (kits Test)}

Determination of the hydrogen peroxide was carried out using a colourimetric method using Mirck M-quant peroxide colourimetric test Kits (Sigma-Aldrich, Germany) with measuring colour range and number of determinations (0.25-0.5-1-2-mg/ $\left.\mathrm{H}_{2} \mathrm{O}_{2}\right)$. Kit strip was put in the milk sample for 5 seconds then it was removed; Blue colour appearance means presence of hydrogen peroxide, compare the result with measuring colour range and number of determinations as- $0.25-0.5-1-2-\mathrm{mg} / \mathrm{H}_{2} \mathrm{O}_{2}$.

\section{Antibiotic detection}

Antibiotic was detected using antibiotic strip (Charm MRLBL1, Charm Sciences, USA) which is specifically designed to detect more betalactam residues in milk at levels closest to established EU and CODEX Maximum Residue Limits (MRLs). The analysis was carried out by adding $300 \mu \mathrm{l}$ of sample to the strip using micro pipette, then the strip was put in the incubator at $55^{\circ} \mathrm{c}$ for $8 \mathrm{~min}$. Appearance of one line indicate positive result and two lines indicate negative result.

\section{Microbiological Examination of Flavoured UHT Milk}

\section{Preparation of samples (APHA, 1992a)}

$10 \mathrm{ml}$ of well mixed milk samples were added to $90 \mathrm{ml}$ of sterile peptone water $0.1 \%$ to make dilution of $1 / 10$ from which 10 -fold serial dilutions were made up.

Total bacterial count (TBC) was estimated by using standard plate count agar (APHA, 1992a). Presumptive coliform count by using lauryl sulphate tryptose (LST) broth and Brilliantgreen Lactose Bile 2\% broth (APHA, 1992a).

Enumeration, isolation and identification of Staphylococcus aureus by using Baired parker's agar (APHA, 1992b).

Yeast and mould count were done by using sabouraud dextrose agar (APHA, 1992b).

Samples were also examined for salmonella, $10 \mathrm{ml}$ of each sample was added to $90 \mathrm{ml}$ of buffere peptone water (Oxoid). After incubation at $37^{\circ} \mathrm{C}$ for $18 \pm 2 \mathrm{hr}$., $0.1 \mathrm{ml}$ of the incubated broth was transferred into $10 \mathrm{ml}$ volume of Rappaport Vassiliadis (RV) (Oxoid) enrichment broth and incubated at $42^{\circ} \mathrm{C}$ for $24 \mathrm{hr}$. Loopfuls of RV broth were streaked onto xylose lysine desoxycholate agar and salmonella-shigella agar (Oxoid). After $24 \mathrm{hr}$., of incubation at $37^{\circ} \mathrm{C}$, presumptive colonies of salmonella were selected and subjected to the further biochemical and serological identification.

\section{Estimation of Chemical Composition of Flavoured UHT Milk (Strawberry and Mango) Samples}

\section{Determination of fat}

Fat was detected using Gerber method.

\section{Determination of total solids (TS) and solids not fat (SNF)}

Total solids percentage was determined by hot air oven according to the method described by AOAC (2006). Solids not fat were measured according to the equation: SNF content $(\%)=$ TS (\%) - Fat (\%)

Determination of protein and lactose in flavoured UHT milk (Automated method).

Milk protein and lactose analyses were carried out using MilkoScan ${ }^{\mathrm{TM}}$ FT1 device (Foss Allé 1DK-3400 Hilleroed, Denmark) which is dedicated to liquid dairy production.

\section{RESULTS AND DISCUSSION}

Food safety and quality control are critical issues that recently have got many interests all over the world mainly from two points of view; the consumer needs exemplified in the nutritional quality and human health.

Various factors may become a source of potential hazards in processed foods including traditional food production accompanied by improper agricultural practices and poor hygienic environment at all food chain stages. In the scientific field of study, safety deals with handling, preparation, and storage of food in ways that prevent foodborne illness (Ahmedsham et al., 2018).

Milk is considered one of the main and common processed foods, it is a complete food 
that contains protein, fat, carbohydrates, many vitamins and minerals that play a significant role in nutrition and health protection (Boza and Sanz Sampelayo, 1997). The nutrient composition of milk varies from one milk sample to another due to a considerable number of factors including the animal breed, age, feed, disease, stage of lactation and also the milking techniques (Ahmedsham et al., 2018).

Quality of milk refers to a blend of characteristics (physical, chemical, microbiological and compositional) that boost up the acceptability of the milk product.

\section{pH and Acidity of Flavoured UHT Milk Samples}

To achieve the gall of the application of Quality assurance, this study contributes to being a survey on processed flavoured UHT milk in Egypt. A comparison among three processed flavoured UHT milk products was carried out. These products belong to three plants and of two flavours; mango and strawberry.

Concerning the physicochemical parameters; results revealed that $\mathrm{pH}$ values ranged between 6.64 and 6.67 for the branded mango flavoured UHT milk and 6.69 for the non-branded mango flavoured UHT milk. For the strawberry flavoured UHT milk; the $\mathrm{pH}$ was in a comparable values among the three milk plants $(6.65,6.6$ and 6.63 ; Figs. 1 and 2).

The acidity in dairy products at any time is a rough indication of the age of the milk and the manner in which it has been handled; so, titratable acidity is defined as a measure of freshness and bacterial activity in milk. When milk is left for a while, the bacteria will proliferate by utilizing lactose to convert it to lactic acid, thereby increasing the acidity and decreasing the $\mathrm{pH}$ value (Ahmedsham et al., 2018).

Inspection of Fig. 3 shows that The acidity of the mango flavoured UHT milk had an apparent acidity as lactic acid (\%) of $0.15 \%$ for brand A and brand $\mathrm{B}$ to $0.13 \%$ for the non branded flavoured UHT milk. This means that the non branded milk acidity was lower than brand A and B. Meantime, strawberry milk acidity revealed lower value $(0.13 \%)$ in brand $A$ than brand $\mathrm{B}$ and the non branded flavoured UHT milk which recorded $0.14 \%$ (Figs. 1 and 2).
However, the $\mathrm{pH}$ and acidity values for all samples recorded in the present study were consistent with those reported in Egypt (El-Kholy et al., 2016) and consistent to the standards of Egyptian Organization for Standardization and Quality of milk Specification No. 1623/2005 (Ecorys Specification) which determined the acidity value as $<0.25 \%$ as lactic acid.

\section{Safety Attributes of Flavoured UHT Milk (Presence of Antibiotic, Formaldehyde and Hydrogen Peroxide) in the Studied Samples}

Table 1 illustrates that there was a presence of antibiotics in $5 \%$ of mango flavoured UHT milk samples under study in brand $\mathrm{A}, 0 \%$ in brand $\mathrm{B}$, where antibiotics were highly presented in the non-branded mango milk (15\%). Strawberry flavoured UHT milk contained antibiotic in the non brand milk with a per cent of $10 \%$ and was clearly absent in brands A and B.

Formaldehyde was completely absent from all samples investigated but peroxide was reported in the non-branded mango and strawberry milk ( $20 \%$ and $5 \%$, respectively). This means that hydrogen peroxide was used in the manufacturing of the non-branded milk for reservation indicating the bad practice in non brand milk processing.

\section{Microbiological Analysis of Milk Samples}

Globally, the occurrence of food borne diseases has been increasing and international food trade has been disrupted by frequently ongoing disputes over food safety and quality requirements (FAO, 2010). To achieve the accepted quality standard, it is mandatory to monitor and control the quality of milk which is the utilization of internationally approved tests to ensure the application of approved practices, standards and regulations concerning the milk and its products (FAO, 2010).

Quality assurance is mandatory before processed food is consumed. It is achieved upon planned and systematic activities performed in each step of the food processing quality systems. Hazard analysis and critical control point systems (HACCP) apply a critical examination through every step of food processing to determine the possibility of having a physical, chemical, or microbiological adjustment. 


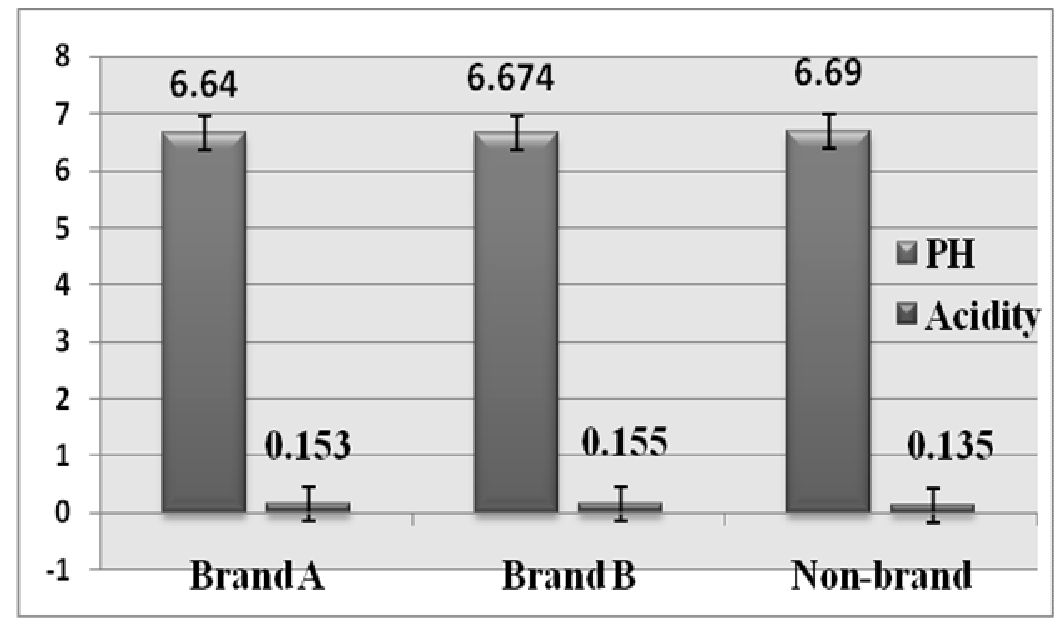

Fig. 1. pH and acidity measurements in brands $A, B$ and non-brand mango milk

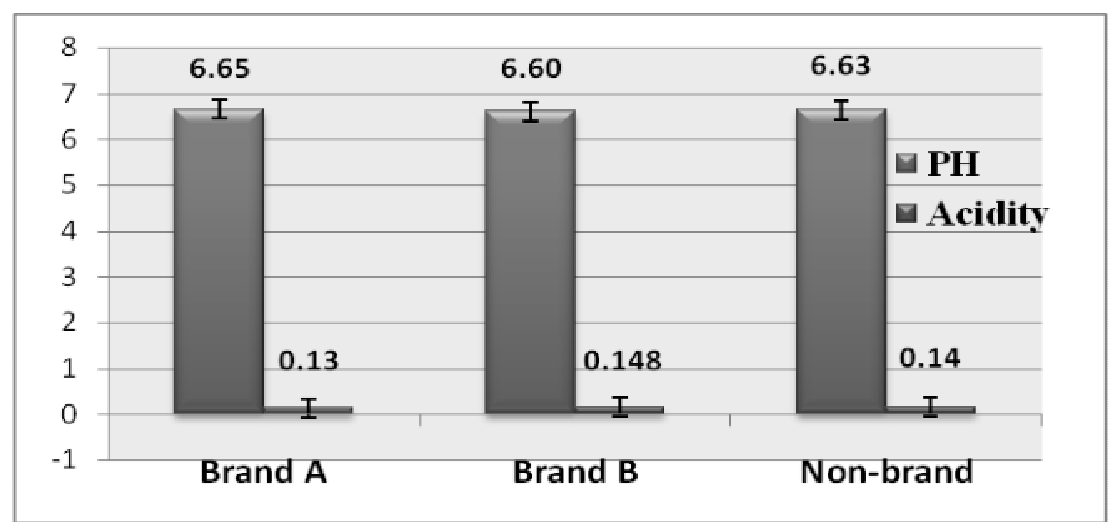

Fig. 2. pH and acidity measurements in brands $A, B$ and non-brand strawberry milk

Table 1. Antibiotic, formaldehyde and hydrogen peroxide detected in mango and strawberry flavoured UHT milk

\begin{tabular}{lcccccc}
\hline Sample & \multicolumn{2}{c}{ Antibiotic } & \multicolumn{2}{c}{ Formaldhyde } & \multicolumn{2}{c}{ Hydrogen peroxide } \\
\cline { 2 - 7 } & Mango & Strawberry & Mango & Strawberry & Mango & Strawberry \\
\hline Brand A (20 samples) & $5 \%$ & 0 & 0 & 0 & 0 & 0 \\
Brand B (20 samples) & 0 & 0 & 0 & 0 & 0 & 0 \\
Non-brand (20 samples) & $15 \%$ & $10 \%$ & 0 & 0 & $20 \%$ & $5 \%$ \\
\hline
\end{tabular}


In this study, milk samples were analyzed for their microbiological quality as a safety indicator which are strictly related to their microbial content. The microbiological results presented in Table 2 for studied flavoured UHT milk samples revealed that, brand $\mathrm{A}$ and $\mathrm{B}$ examined milk samples had good bacteriological quality where the TBC in all examined mango flavoured UHT samples was $<10 \mathrm{cfu} / \mathrm{ml}$ and in all strawberry flavoured UHT milk it was $<5 \mathrm{cfu} / \mathrm{ml}$.

It is evident also that coliforms nearly not detected in all examined samples of mango flavoured UHT milk with a mean value of $<3$ $\mathrm{MPN} / \mathrm{ml}$ and $<5 \mathrm{MPN} / \mathrm{ml}$ in the non-branded strawberry flavoured UHT milk. Salmonella failed to be detected in all examined samples of milk. Staphylococcus aureus was poorly detected in all samples under study $(<10 \mathrm{cfu} / \mathrm{ml})$ and yeast and mold was $<5$ in all samples (Table 2 ).

Milk serves as an ideal medium for the growth of many organisms because of its nearneutral $\mathrm{pH}$, complex biochemical composition and high water content. Gamal et al. (2015) in their study said that; fresh milk drawn from a healthy cow normally contains a low microbial load $\left(<10^{3} \mathrm{CFU} \mathrm{ml}{ }^{-1}\right)$. But the load may increase up to 100 fold or more once it is stored for some time at ambient temperature (Ahmedsham et al., 2018).

Therefore, keeping milk in clean containers at refrigeration temperatures immediately after the milking process may delay the increase of initial microbial load and prevent the multiplication of microorganisms in milk between milking at the farm and transportation to the dairy plant (Chye et al., 2004). Milk and dairy products can be damaged by a variety of microorganisms, including many zoonotic bacteria and some viruses for example, retroviruses and cytomegalovirus (Kaufmann and Aart, 2002). In Egypt, the dairy industry uses a heat treatment process to ensure the safety of fluid milk and to extend its shelf life (Metwally et al., 2011).

The total bacterial count (TBC) of flavoured UHT milk studied samples is indicating the health status, farm sanitation, and milk storage temperature. Bacterial strains of Escherichia coli, Salmonella and others are often implicated in milk-borne diseases (Steel et al., 2004).
In this study, the microbiological data presented for examination of studied flavoured UHT milk samples revealed that, TBC was not detected from any of the branded milk samples (A and B) mango and strawberry flavoured UHT milk, so brands A and B had good bacteriological quality where the TBC in examined samples was $<10 \mathrm{cfu} / \mathrm{ml}$. This result is consistent with the Egyptian Organization for Standardization and Quality of milk Specification No. 1623/2005 for microbiological regulation and hence it is clearly indicating efficiency of the applied processing conditions to kill the microorganisms and the good hygienic practice in the two branded plants, to avoid cross-contamination, and inability of pathogens (El-Ziney et al., 2018). Nearly similar results were reported by Piotrowska et al. (2015) for the processed flavoured milk. While higher results were reported by Osama et al. (2014) and El-Kholy et al. (2016) in UHT milk in Egypt.

TBC in the non-branded milk showed 15\% ratio in the strawberry milk, this result doesn't probably consistent with the Ecorys microbiological regulation that considers UHT milk is conform to specifications at TBC of $<10$ cells/gm (cfu/g).

Salmonella was completely absent in all samples, also Staphylococcus aureus failed to be detected in brands A and B examined samples of milk. These results are in accordance with Osama et al. (2014) for processed UHT milk except the positive ratio $(5 \%)$ was detected in strawberry non-branded UHT flavoured milk.

The presence of coliforms in processed products is used as indicator for the possibility contamination, unsanitary conditions or practices during production, processing or storage (Robinson, 2002). Coliforms nearly were not detected in all examined samples of brands A and $\mathrm{B}$ milk with a mean value of $<3 \pm 0$ (MPN/ml. Comparable results of total coliforms in processed milk were reported by Piotrowska et al. (2015) and El-Kholy et al. (2016) but higher results were reported by Saxena and Rai (2013) for processed milk. Inspection of the obtained results from non-branded milk indicates that sanitary conditions during manufacturing, handling and distribution was not very good, where some of the examined samples even few were contaminated with coliforms $(5 \%$ in mango milk and $10 \%$ in strawberry milk). 
Table 2. Total bacterial count (TBC), total coliform count, Staphylococcus aureus count and salmonella and yeast and mold counts in examined flavoured UHT milk

\begin{tabular}{|c|c|c|c|c|c|c|c|c|c|c|c|c|c|}
\hline \multicolumn{2}{|c|}{ Milk sample and variable } & \multicolumn{5}{|c|}{ Brand A } & \multicolumn{3}{|c|}{ Brand B } & \multicolumn{4}{|c|}{ Non-brand } \\
\hline & & $\overline{+v e}$ & Min. & Max. & $\begin{array}{l}\text { Mean } \\
\pm \text { SD }\end{array}$ & + +ve & Min. & Max. & $\begin{array}{l}\text { Mean } \\
\pm \text { SD }\end{array}$ & ve & Min. & Max. & $\begin{array}{c}\text { Mean } \\
\pm \text { SD }\end{array}$ \\
\hline Mango & TBC(cfu/ml) & $\mathbf{0}$ & $<10$ & $<10$ & $\mathbf{0}$ & $\mathbf{0}$ & $<10$ & $<10$ & $\mathbf{0}$ & $\mathbf{0}$ & $<10$ & $<10$ & $\mathbf{0}$ \\
\hline milk & Total coliform(MPN/ml) & $\mathbf{0}$ & $<2$ & $<2$ & $\mathbf{0}$ & $\mathbf{0}$ & $<2$ & $<2$ & $\mathbf{0}$ & 1 & $<3$ & $<3$ & $\mathbf{0}$ \\
\hline \multirow[t]{3}{*}{ (20 samples) } & Staphylococcus aureus (cfu/ml) & $\mathbf{0}$ & $<10$ & $<10$ & $\mathbf{0}$ & $\mathbf{0}$ & $<10$ & $<10$ & $\mathbf{0}$ & $\mathbf{0}$ & $<10$ & $<10$ & $\mathbf{0}$ \\
\hline & Salmonella & $\mathbf{0}$ & $\mathbf{0}$ & $\mathbf{0}$ & $\mathbf{0}$ & $\mathbf{0}$ & $\mathbf{0}$ & $\mathbf{0}$ & $\mathbf{0}$ & $\mathbf{0}$ & $\mathbf{0}$ & $\mathbf{0}$ & $\mathbf{0}$ \\
\hline & Yeast and mold (cfu/ml) & $\mathbf{0}$ & $<3$ & $<3$ & $\mathbf{0}$ & $\mathbf{0}$ & $<3$ & $<3$ & $\mathbf{0}$ & 1 & $<5$ & $<5$ & $\mathbf{0}$ \\
\hline Strawberry & TBC(cfu/ml) & $\mathbf{0}$ & $<\mathbf{3}$ & $<\mathbf{3}$ & $\mathbf{0}$ & $\mathbf{0}$ & $<1$ & $<1$ & $\mathbf{0}$ & 3 & $<5$ & $<5$ & $\mathbf{0}$ \\
\hline milk & Total coliforms (MPN/ml & $\mathbf{0}$ & $<2$ & $<2$ & $\mathbf{0}$ & $\mathbf{0}$ & $<\mathbf{3}$ & $<\mathbf{3}$ & $\mathbf{0}$ & 2 & $<5$ & $<5$ & $\mathbf{0}$ \\
\hline \multirow[t]{3}{*}{ (20 samples) } & Staphylococcus aureus (cfu/ml) & $\mathbf{0}$ & $<10$ & $<10$ & $\mathbf{0}$ & $\mathbf{0}$ & $<10$ & $<10$ & $\mathbf{0}$ & 1 & $<10$ & $<10$ & $\mathbf{0}$ \\
\hline & Salmonella & $\mathbf{0}$ & $\mathbf{0}$ & $\mathbf{0}$ & $\mathbf{0}$ & $\mathbf{0}$ & $\mathbf{0}$ & $\mathbf{0}$ & $\mathbf{0}$ & $\mathbf{0}$ & $\mathbf{0}$ & $\mathbf{0}$ & $\mathbf{0}$ \\
\hline & Yeast and mold (cfu/ml) & $\mathbf{0}$ & $<\mathbf{3}$ & $<\mathbf{3}$ & $\mathbf{0}$ & $\mathbf{0}$ & $<\mathbf{3}$ & $<\mathbf{3}$ & $\mathbf{0}$ & 3 & $<5$ & $<5$ & $\mathbf{0}$ \\
\hline
\end{tabular}

Yeasts and moulds were detected just in the non-branded UHT milk (5\% of mango and $15 \%$ of strawberry milk). The presence of such organisms in high numbers is objectionable as they render the dairy products of inferior quality and unfit for human consumption; As well as, the previously mentioned organisms are considered indicator for the quality of dairy products, but actually the presence of these organisms in the non-branded milk was not consistent with the Ecorys Specification/2005 for microbiological regulation. Therefore, the good quality and safe milk should produced under strict hygienic conditions a better processing treatment should be used in the manufacturing in this plant (Non-branded milk) to improve its quality.

\section{Chemical Composition of Flavoured UHT Milk}

Non-branded flavoured UHT milk showed higher fat content (1.81 and 1.64) in mango and strawberry UHT milk, respectively, but lower in all other ingredients (protein, solids not fat (SNF), total solids (TS) and lactose). Results in Figs. 3 and 4 showed that brand $\mathrm{A}$ was higher than brand B in each of protein (3.32 and 3.09), lactose (12.24 and 11.77) and TS (18.14 and 19.11) contents, as well as brand A was lower than brand B in each of SNF (16.31 and 16.65) and fat (1.68 and 1.1.73) contents, respectively.

Fig. 4 illustrates the chemical composition of strawberry UHT milk ingredients, protein and SNF content was higher in brand A, TS and lactose content was higher in brand $\mathrm{B}$.

In studied samples, the fat content of the mango non-branded flavoured UHT milk was higher (1.81\%) than the branded flavoured UHT milk $\mathrm{A}$ and $\mathrm{B}(1.68 \%, 1.73 \%)$ respectively. Strawberry non-branded milk was higher in fat (1.64) than the branded UHT milk A and B $(1.61 \%, 1.6 \%)$ respectively. Protein, SNF, TS and lactose measurements were lower than those of the brands A and B in mango and strawberry UHT milk. The comparison between brands A and $\mathrm{B}$ revealed that brand $\mathrm{A}$ was higher in protein $(3.32,3.09$, respectively) and lactose $(12.24,11.77$, respectively) content, but was lower in SNF, TS and fat. The accuracy in fat determination could be obtained by good mixing conditions as fat has the tendency to float on the surface of the milk, for this reason the samples were well shacked before fat checking. The differentiation of milk fat in different layers was reduced by higher homogenization pressure (Chun et al., 2013). 


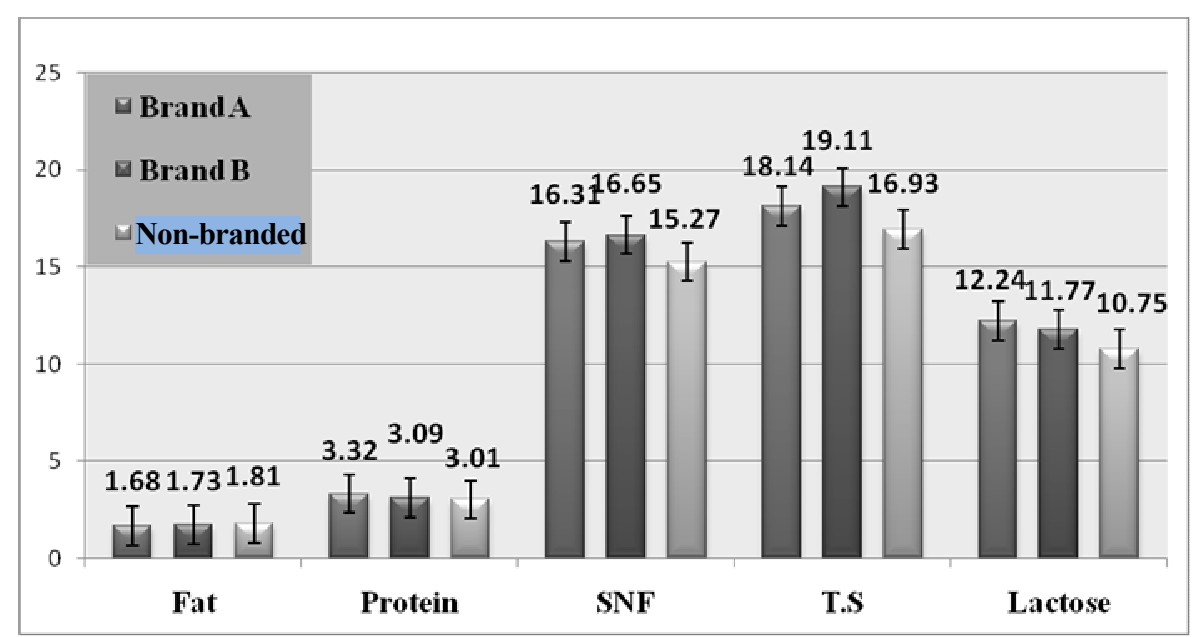

Fig. 3. Chemical composition of brands A, B and non-branded mango flavoured UHT milk

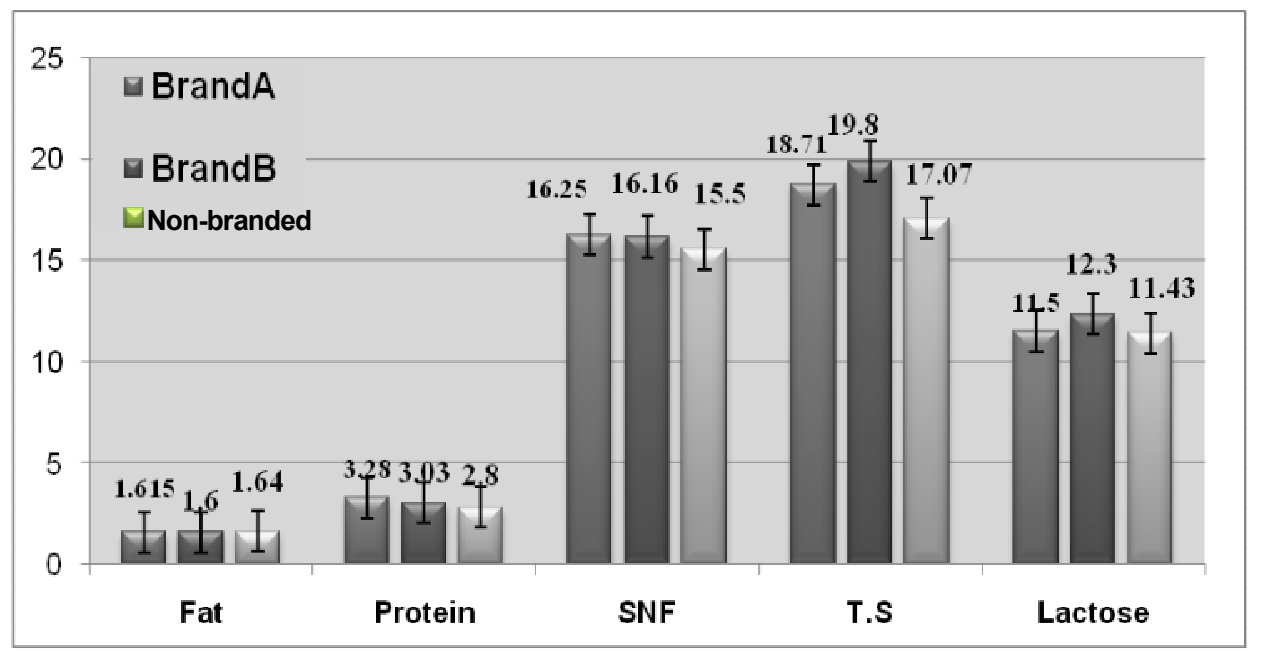

Fig. 4. Chemical composition of brands A, B and non-branded strawberry flavoured UHT milk

However, fat content recorded in all samples under study were not consistent with the Egyptian Organization for Standardization and Quality of UHT milk Specification No. 1623/ 2005 which indicate that fat content shouldn't be lower than $3 \%$. This results almost due to the bad manufacturing practice of UHT milk. The results showed that the non-branded fat content was higher than that of the branded milk. This may be due to using of powder milk in processing but still out of the Egyptian specification.

Difference of total solids (TS) and solid not fat (SNF) among all samples is due to the standardized chemical composition of fresh milk before processing. However TS and SNF values were consistent with the Egyptian UHT milk specification $(\geq 15 \%)$. Our results are not in agreement with those obtained by Barbano et al. (2006), Nour-Eldin et al. (2013) and Aldubhany et al. (2014) who found a decrease in TS UHT than the Egyptian Standards. This may be due to long storage period.

Lactose in all investigated samples (Branded/ non-branded) was ranging from 10.75 to 12.24 in mango milk and from 11.43 to 12.3 in strawberry milk. So this result is higher than that recommended in Egyptian UHT milk Specification Standards (About 5\% as transformed sugar). El-Neshawy et al. (1988) in their study indicated that reduced lactose dairy products have a potential for incorporation into reduced calories forms, consequently healthy food. 
Protein content analysis of mango and strawberry UHT milk revealed comparable values among samples of branded and nonbranded factories with lower value in the later. As storage period progresses, protein content gradually decreases and degrade in the processed food may be owing to enzymatic hydrolysis; This may be due to the reason for elimination or exclusion of protein content from the Egyptian Standards.

According to Shihabul et al. (2016) protein of milk is highly affected by heating and storage period. The protein decrease in UHT milk during storage may be due to enzymatic hydrolysis. Most of milk proteins coagulate after heating, hence casein polymerization is greater at high storage temperature, but occurs significantly even under refrigerator condition. This result agreed with those of Chun et al. (2013).

In developing countries, various factors combine to compromise the hygienic quality of milk products: the organization of milk supply chains themselves, the regulatory systems and quality control structures. The problem is compounded by local climatic conditions, where both heat and, at times, humidity do not favor the preservation of the product in optimal conditions when the cold chain cannot be maintained.

Two alternative approaches are used in the world to ensure the safety of dairy products. In the united states, control and sterilization are the predominant methods, whereas in Europe quality and safety are managed all along the supply chain. In light of the situation observed in tropical countries and the results obtained in Europe, it seems opportune to promote the latter approach to guarantee the dairy product safety in Egypt as Egypt has a high degrees climatic temperatures. The management of the quality by risk analysis or identification of potential hazards linked to a product or a process (Hazard Analysis and Critical Control Points or HACCPtype approach), must be applied along the whole supply chain from the cow to the consumer (El-Hofi et al., 2010).

Identification of the potential risk in the manufacturing processes help correction actions and control plans, considering the probability that the exposure to a particular risk can cause a disease for a given individual.

As the Critical Control Point (CCP) which is a step at which control can be applied and is essential to eliminate or prevent a food safety hazard to occur, it is justified by the fact that at this point if there is a fault in the time and temperature may occur persistence of pathogenic microbs. Microorganisms can develop during storage reducing the quality of the product.

Packaging is also considered a CCP, when packaging is performed incorrectly will contribute to low quality in the storage step. So, it is recommended to implementation of complete analyses for the raw milk before processing to establish comply with Egyptian law and ensuring the safety of the product offered to the population.

Although there was a ratio of the total samples analyzed in this study were following the Egyptian UHT milk Specification law, samples of the non branded milk were lacking these specification, the problem is that this type of milk supply chains are distributed in many governorates in Egypt. So, further pursuit and researches should be carried out to realize more safety and quality assurance in the processed food.

\section{REFERENCES}

Ahmedsham, M., N. Amza and M. Tamiru (2018). Review on milk and milk product safety, quality assurance and control Int. J. Livestock Prod., 9 (4): 67-78.

Aldubhany, T.A.W., E. Gouda, A. Khattab, and N. Dabour (2014). Effects of storage on some physico-chemical characteristics of UHT milk stored at different temperature. Alex. Sci. Exchange J., 3 (2): 107-114.

Anonymous (2005). Quality Control for Processed Foods.

AOAC (1990). Official Methods of Analysis, $14^{\text {th }}$ Ed. Association of Official Analytical Chemists. Washington D.

AOAC (2006). The Official Methods of Analysis of AOAC. Int. $18^{\text {th }}$ Ed., The Association of Official Analytical Chemists, 
Arlington, USA. Available in Dhaka City, Bangladesh. Mal J. Nutr., 431-438.

APHA (1992a). Standard Methods for the Examination of Water and Wastewater, $18^{\text {th }}$ Ed., American Public Health Association/ American Water Works Association/Water Environ. Federation, Washington, DC, 438439.

APHA (1992b). Standard Methods for the Examination of Water and Wastewater, $18^{\text {th }}$ Ed., American Public Health Association/ American Water Works Association/Water Environ. Federation, Washington, DC, 445446.

Barbano, D.M., Y. Ma and M.V. Santos (2006). Influence of raw milk quality on fluid milk shelf-life. J. Dairy Sci., 89 (1): 15-19.

Boza, J. and M.R. Sanz Sampelayo (1997). Nutritional aspect of goat milk. An. Acad. Cienc. Vet. Andalucía Oriental, 10: 109-139.

Chun L.U., G. Wang, L. Yan and L. Zhang (2013). Effects of homogenization pressures on physicochemical changes in different layers of ultra-high temperature whole milk during storage. Int. J. Dairy Tech., 66 (3): 325-339.

Chye, F.Y., A. Abdullah and M.K. Ayob (2004). Bacteriological quality and safety of raw milk in Malaysia. J. Food Microb., 21: 535541.

Dias, S.S., V.C. Barbosa and S.R.R. Costa (2010). Utilização do APPCC como ferramenta da qualidade em indústrias de alimentos. Rev. Ciênc Vida, Seropédica, 30 (2): 99-111.

El-Hofi, M., E.S. El-Tanboly and A. Ismail (2010). Implementation of the Hazard Analysis Critical Control Point (Haccp) System to Uf White Cheese Production Line .Acta Sci. Pol., Technol. Aliment. 9 (3): 331342. University of Georgia Cooperative Extension Bulletin 997. Quality Control: A Model Program for the Food Industry.

El-Kholy, A., S. El-shinawy, G. Hassan and B. Morsy (2016). Quality assessment and safety system of milk and some milk products in university hostel. J. Food Sci. and Quality Manag., 50: 86-93.
El-Neshawy, A.A., S.M. Farahat and H.A. Wahbah (1988). Organoleptic and physical properties of ice cream made from hydrolysed lactose reconstituted milk. J. Food Chem., 27:83-93.

El-Ziney, M.G., A.S. Ammar and A.I. Al-Turki (2018). Effectiveness of groundwater treatment for drinking use and dairy and food processing. J. Advances in Dairy Res., 6:1.

FDA (2001). Food and Drug Administration. FDA Publishes Final Rule to Increase Safety of Fruit and Vegetable Juices.

Floros, J.D., R. Newsome, W. Fisher, G.V. Barbosa-Canovas, H. Chen, C.P. Dunne, J.B. German, R.L. Hall, D.R. Heldman, M.V. Karwe, S.J. Knabel, T.P. Labuza, D.B. Lund, M. Newell-McGloughlin, J.L. Robinson, J.G. Sebranek, R.L. Shewfelt, W.F. Tracy, C.M. Weaver and G.R. Ziegler (2010). Feeding the world today and tomorrow: The importance of food science and technology-An IFT scientific review. Compr. Rev. Food Sci. Food Saf, 9:572-599.

Gamal, M.H., M.S. Arafa and M.G. Soad (2015). Microbiological quality and safety of fluid milk marketed in Cairo and Giza Governorates. Cur. Res. in Dairy Sci., 7 (1): $18-25$.

Jay, J.M., M.J. Loessner and D.A. Golden (2005) Modern Food Microbiology. $7^{\text {th }}$ Ed., Springer Science and Business Media, Inc., New York, 63 (90): 101-125.

Kaufmann, D. and K. Aart (2002). Growth Without Governance. World Bank Policy Research Working Paper No. 2928, Washington, D.C.

Langelaan, H.C., F. Pereira da Silva, U. Thoden van Velzen, J. Broeze, A.M. Matser, M. Vollebregt and K. Schroën (2013). Technology options for feeding 10 billion people Options for sustainable food processing. State of the art report.

Metwally, A.M.M., M.A.D. Nadia, W.I. ElKholy and I.S. Zeinab (2011). The effect of boiling on milk microbial contents and quality. J. Ame. Sci., 7 (2): 110-114.

Nour-Eldin M.F.H., Y.I. Abdel-Kader and M.A. Shahin (2013). Analysis of representative samples of UHT sterilized milk in the Egypt. 
market. Ame. J. Food, Nutr. and Health. 2(6): 31-42.

Osama, M.S., A.I. Gamal, F.T. Nabil, A.M.E. Baher, E. Kawther, M.F.E. Hala and M.A.S. Moussa (2014). Prevalence of some pathogenic microorganisms in factories Domiati, Feta cheeses and UHT milk in relation to public health sold under market conditions in Cairo. Int. J. Chem. Tech. Res., 6 (5): 2807-2814.

Piotrowska, A., F. Świderski, E. Kostyra, M. Żebrowska-Krasuska and A. Sadowska (2015). Microbiological and sensory quality of milk on the domestic market. Polish J. Food and Nutr. Sci., 65 (4): 261-267.
Robinson, R.K. (2002). Dairy Microbiology Hand Book. $3^{\text {rd }}$ Ed.

Saxena, M. and P. Rai (2013). Microbiological and chemical analysis of raw, pasteurized and UHT milk during preservation in India. Int. J. Chem. Technol. Res., 5 (6):2804-2809.

Shihabul, A.M.D., H.M.D. Raihanul, H.S.M. Kamrul and A.M.D. Ruhul (2016). Evaluation of physico-chemical properties and detection of adulterants of UHT milk samples. Int. Res. J. Biol. Sci., 5 (2): 1-6.

Steel, M.L., M.B. MacNab, C. Pope, M.W. Griffiths and S. Chen (2004). Survey of ontario bulk tank milk for foodborn pathogens. J. Food Prot., 60: 1341-1346.

\section{تقيــــم الجــودة والســلامة للبن المنكة المعقم المتداول في السوق المصريـ دراسة مســـية للمراقبة الصحية المئية}

\section{إسلام عاطف عبد الغفار- أحمد علاء الدين النشوي- حسن محمد صليحة - جيهان عبدالله الشوربجي}

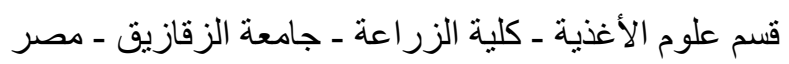

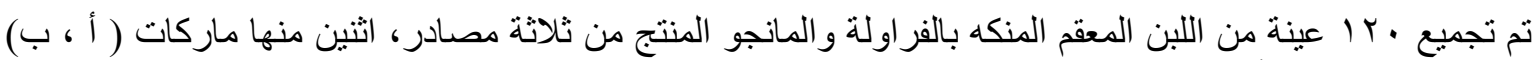

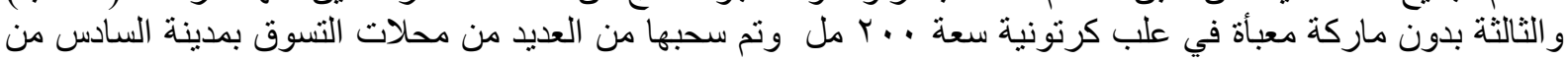

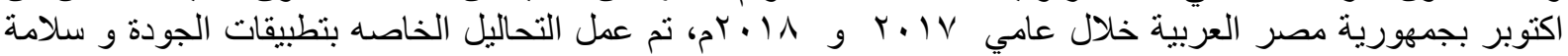

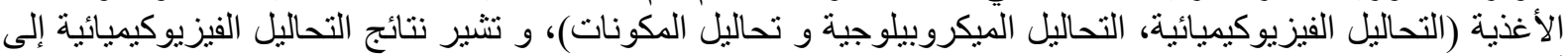

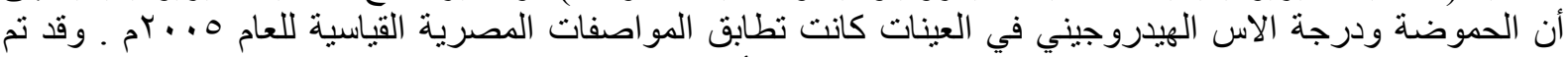

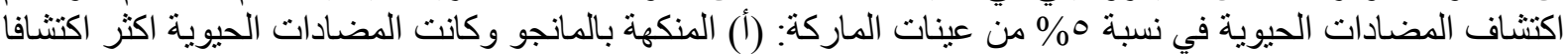

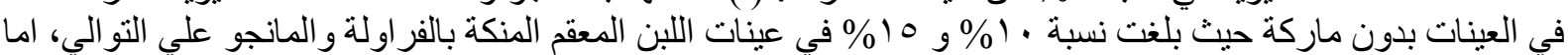

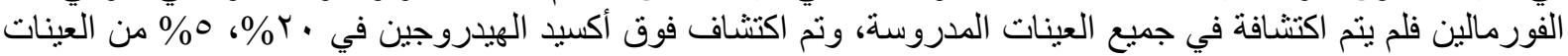

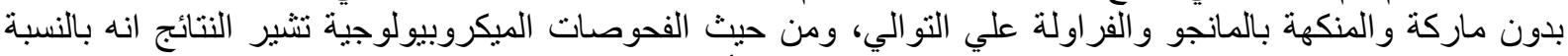

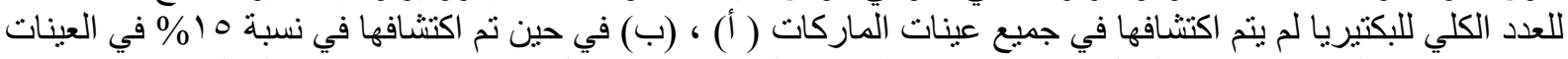

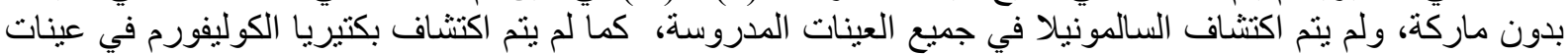

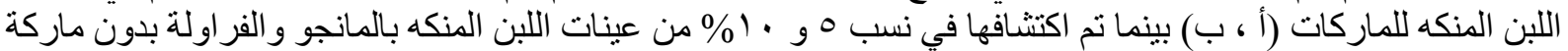

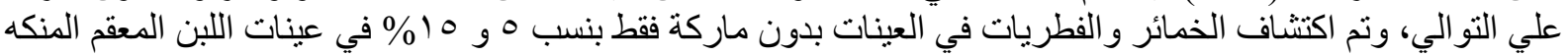

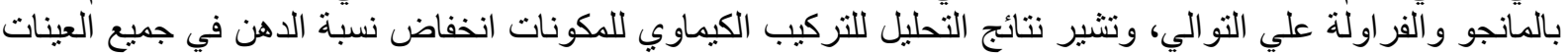

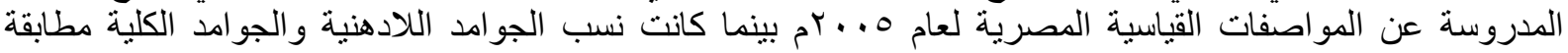

